Beata Gtowacka, Dariusz Chrzęszczyk, Tomasz Konopka

\title{
REASONS AND RISK INDICATORS FOR TOOTH LOSS IN THE POLISH CROSS-SECTIONAL GERODONTOLOGICAL STUDY
}

\author{
PRZYCZYNY I WSKAŹNIKI RYZYKA UTRATY ZĘBÓW W POLSKIM \\ PRZEKROJOWYM BADANIU GEROSTOMATOLOGICZNYM
}

Wrocław Medical University Department of Periodontology

Uniwersytet Medyczny we Wrocławiu Katedra i Zakład Periodontologii

\begin{abstract}
INTRODUCTION. The number of teeth in the elderly is the most essential epidemiological data in gerodontological studies. It depends mainly on two medical causes in the form of caries and periodontitis, as well as many risk factors and indicators for tooth preservation and loss.

The goals of the cross-sectional study among the residents of Wrocław and Oława aged 65-74 have been to assess the number of preserved teeth, severe tooth loss and edentulism in a 30-year trend and in relation to current European regional data. In addition, the most important risk indicators for tooth preservation and loss in the assessed population will be determined.

MATERIAL AND METHODS. After applying the two-tier stratification method from a group of 1,200 people, 387 volunteered for the study. The examination was conducted in dental offices in Wrocław and Oława, it consisted from clinical and anamnestic parts. The average number of preserved teeth in the entire group was 13.07 (median 15), there were $21.2 \%$ persons with functional dentition, $21.4 \%$ with severe tooth loss and $14.2 \%$ with edentulism. The main direct reason of tooth loss was caries and its complications, which concerned $81.9 \%$ of the teeth removed, on average over 12 teeth in the examined person.

RESULTS. Referring the results of the obtained study to previous observations can be seen, that in the 30year trend for Wrocław in people aged 65 to 74 years, the average number of teeth as well as the percentage of edentulism have improved, but they are still worse than the results of regional European studies. The main risk indicators of earlier loss of teeth by seniors in Lower Silesia are low income, past incorrect pro-health behaviours towards the oral cavity as well as current smoking and history of cardiovascular incidence.
\end{abstract}

Key words: tooth loss, edentulism, cross-sectional study, elderly, risk indicators.

\section{STRESZCZENIE}

WSTĘP. Liczba zębów u osób starszych jest najważniejszym parametrem epidemiologicznym w badaniach gerostomatologicznych. Zależy ona zasadniczo od dwóch przyczyn medycznych: próchnicy oraz zapalenia przyzębia oraz wielu czynników i wskaźników ryzyka zachowania i utraty zębów.

CEL.Celami przekrojowego polskiego badania regionalnego osób w wieku od 65 do 74 lat z Wrocławia i Oławy były ocena liczby zachowanych zębów, ciężkiej utraty zębów i bezzębia oraz ich porównanie z badaniami z ostatnich 30-lat. Dodatkowo wyniki tych obserwacji będą odniesione do aktualnych regionalnych danych europejskich, a także zostaną ustalone najważniejsze wskaźniki ryzyka zachowania i utraty zębów w ocenianej populacji.

MATERIAŁ I METODY. Po zastosowaniu metody losowaniu dwuwarstwowego z grupy 1200 osób na badanie zgłosiło się 387. Badanie prowadzono w gabinetach stomatologicznych we Wrocławiu i Oławie, składało się na nie badanie kliniczne i anamnestyczne. Średnia liczba zachowanych zębów w całej grupie wynosiła 13,07 (mediana 15), osób z zachowanym funkcjonalnym uzębieniem było 21,2\%, z ciężką utratą zębów 21,4\%, a bezzębnych 14,2\%. Główną bezpośrednią przyczyną utraty zębów była próchnica i jej powikłania, co dotyczyło 81,9\% usuniętych zębów, średnio ponad 12 zębów u badanego.

WYNIKI. Odnosząc wynik uzyskanych badań do obserwacji wcześniejszych można zauważyć, że w 30-letnim okresie dla Wrocławia u osób w wieku od 65 do 74 lat średnia liczba zachowanych zębów, jak również odsetek 
bezzębia poprawiają się, lecz są jednak nadal gorsze od wyników regionalnych badań europejskich. Głównymi wskaźnikami ryzyka wcześniejszej utraty zębów przez seniorów dolnośląskich są niski dochód oraz wcześniejsze zaniedbania zdrowia jamy ustnej, a także aktualny nikotynizm i przebyty incydent sercowo-naczyniowy.

Słowa kluczowe: utrata zębów, bezzębie, badanie przekrojowe, osoby starsze, wskaźniki ryzyka

\section{INTRODUCTION}

The decrease in the number of teeth is observed with the transition to older age groups. The main medical causes of tooth extraction in adults are caries and periodontitis, and much less frequently these are prosthetic indications, injuries and dental iatrogeny $(1,2)$. There are also numerous risk indicators and factors for tooth loss, such as: socio-economic (education level, income, type of funding of dental services), behavioral (the patient's attitude towards dental treatment, doctor's attitude), medical (smoking, uncontrolled diabetes mellitus, malnutrition) geographic and demographic (for instance, the number of dentists per 100000 residents) $(3,4)$.

It has been shown that the dynamics of tooth loss varies depending on the age of the subjects and is the highest in the fifth and sixth decade of life for developed countries (1). Also, the share of the two most common reasons for tooth extraction is determined by age. The cariological causes are by far the most common medical cause of tooth loss in general and in people aged 40-44 $(3,5)$. Above this age, in developed countries, periodontal indications start to prevail and they concern even $76-78 \%$ of tooth extractions (2).

The number of preserved teeth is one of the criteria for assessing oral health. Maintaining natural, healthy teeth or their reconstruction by conservative and prosthetic dentistry is one of the determinants of successful aging (6). According to the WHO (7), the reduced dentition may be efficient, provided that it retains the function of chewing and speech as well as aesthetics. For epidemiological purposes, in turn, a quantitative definition of functional dentition is used, with the presence of at least 21 healthy teeth (8).

Teeth loss is considered a form of disability that affects the quality of life of older people regardless of the type of dental prostheses. It involves aesthetic, functional, psychological and social consequences. To determine the advancement of tooth loss, the concept of severe tooth loss has been introduced. It defines the presence of fewer than 10 natural teeth in the oral cavity, which significantly affects the type of diet (9). In the previous two decades, a $45 \%$ reduction has been observed globally in the rate of new patients with severe tooth loss/100,000 people/year (10). A similar trend, related to the presence of less than 10 teeth in oral cavity, was observed: in 2010 it was $4.4 \%$, showing the decrease by half as compared to 1990 (10). The basis

\section{WSTĘP}

Wraz ze starzeniem się populacji osób dorosłych dochodzi do zmniejszania się liczby zachowanych zębów. Głównymi przyczynami medycznymi ekstrakcji zębów u dorosłych są próchnica i zapalenie przyzębia, zdecydowanie rzadziej są nimi urazy, wskazania protetyczne, jatrogenia stomatologiczna $(1,2)$. Występuje także szereg wskaźników i czynników ryzyka utraty zębów, takich jak: uwarunkowania socjalno-ekonomiczne (poziom wykształcenia, dochód, rodzaj finansowania usług medycznych), behawioralne (nastawienie pacjenta do leczenia stomatologicznego, postawa lekarza), medyczne (nikotynizm, niekontrolowana cukrzyca, niedożywienie) geograficzne i demograficzne (np. liczba dentystów na 100 tys. mieszkańców) $(3,4)$.

Dynamika utraty zębów zmienia się w zależności od wieku badanych i dla krajów rozwiniętych największa jest w piątej i szóstej dekadzie życia (1). Oddziaływanie dwóch najczęstszych przyczyn utraty zębów również zmienia się wraz z wiekiem. Próchnica stanowi zdecydowanie najczęstszą medyczną przyczynę utraty zębów w ogóle oraz u osób od 40 do 44 roku życia $(3,5)$. Powyżej tego wieku w krajach rozwiniętych zaczyna przeważać przyczyna periodontologiczna będąca powodem nawet od 76 do $78 \%$ ekstrakcji zębów (2).

Liczba zachowanych zębów jest jednym z kryteriów oceny stanu zdrowia jamy ustnej. Utrzymanie naturalnego, zdrowego uzębienia lub jego odbudowa przez leczenie zachowawcze lub stałe uzupełnienia protetyczne stanowi jeden z wyznaczników pomyślnego starzenia się (successful ageing) (6). Według WHO (7) za wystarczające może być uznane zredukowane liczbowo uzębienie, pod warunkiem, że zapewnia ono funkcję żucia i mowy oraz estetykę. Z kolei do celów epidemiologicznych stosowana bywa ilościowa definicja uzębienia czynnościowego (functional dentition) określająca zachowanie przynajmniej 21 zębów własnych (8).

Utrata zębów uważana jest za formę niepełnosprawności wpływającej na jakość życia osób starszych niezależnie od zaopatrzenia protezami zębowymi. Dla określenia zaawansowanej utraty zębów wprowadzono pojęcie ciężkiej utraty zębów (severe tooth loss). Definiuje ono obecność w jamie ustnej mniej niż 10 zębów, co istotnie wpływa na rodzaj przyswajanej diety (9). W skali ogólnoświatowej w ostatnich dwóch dekadach zaobserwowano $45 \%$ obniżenie wskaźnika nowych osób z ciężką utratą zębów na 100000 ludności w roku (10). U podstaw tych korzystnych zmian leży prawdopodobnie postęp w sto- 
for these beneficial changes is probably the progress in dentistry and effective interventions observed in many parts of the world, regarding the health of population, including - among others - caries prophylaxis (11).

In Polish epidemiological studies in 2002 and 2009, the average number of teeth preserved in people aged 65-74 was, respectively, 6.3 and 6.6 teeth per person (12). Compared to the average number of teeth in 70-year-old Swedes, which in 2005 was 20.7 teeth (13), this was a very poor result. The percentage of edentulous people in the Polish population aged 65-74 in the first decade of the $20^{\text {th }}$ century exceeded $40 \%$. It was $41.6 \%$ in 2002 and $43.9 \%$ in 2009 (12). The global oral health goal by WHO for 2010, assuming that the number of toothless people will be less than $5 \%$ of the population aged 65-74 (8), was never met in Poland.

To assess the trend, it is necessary to periodically repeat gerodontological studies. The goals of the crosssectional study among the residents of Wrocław aged 65-74 have been to assess the number of preserved teeth, severe tooth loss and edentulism in a 30-year trend and in relation to current European regional data. In addition, the most important risk indicators for tooth preservation and loss in the assessed population will be determined.

\section{MATERIAL AND METHODS}

The examination was conducted among persons aged 65-74, living in a city (Wrocław, 638,000 inhabitants) and a small town (Oława, 33,000 inhabitants), within the province of Lower Silesia in Poland. At the Ministry of the Interior and Administration in Warsaw, Poland's capital city, a two-tier (gender and age) stratification method was used in order to select a group of people for the epidemiological study. As a result, a group of 1200 inhabitants of the Wrockaw region was selected (800 and 400 people for Wrocław and Oława respectively), with a symmetrical structure of gender and age. Letters inviting these persons to participate in a free oral health examination were sent; persons for whom a valid phone number was established were additionally notified by telephone. The invitation contained information that if indications for dental treatment would be stated there was possibility of such treatment under procedures funded by the NFZ (National Health Fund).

The research was carried out in the Department of Periodontology at the Medical University of Wrocław and in a private specialist dental office in Oława (Dentyści Oława). The participants of the study signed a statement approved by the Bioethical Commission at the Medical University of Wrocław (opinion no. KB$712 / 2017$ ), thereby agreeing to participate in the study and to process the obtained data. The applied exclusion criteria were as follows: general contraindications matologii oraz obserwowana $\mathrm{w}$ wielu rejonach świata skuteczna interwencja w stan zdrowia populacji, dotycząca m.in. profilaktyki próchnicy (11).

W polskich badaniach epidemiologicznych średnia liczba zachowanych zębów u osób w przedziale wieku od 65 do 74 lat wynosiła w latach 2002 i 2009 odpowiednio 6,3 i 6,6 zęba u osoby (12). W porównaniu do średniej liczby zębów u 70-letnich Szwedów, która w 2005 roku wynosiła 20,7 zęba (13], był to wynik bardzo zły. Udział osób bezzębnych w populacji polskiej w wieku od 65 do 74 lat w pierwszej dekadzie XX. wieku przekraczał $40 \%$. Wynosił odpowiednio $41,6 \% \mathrm{w} 2002$ r. oraz $43,9 \%$ w 2009r (12). Cel wytyczony przez WHO na 2010 rok zakładający, że osoby bezzębne będą stanowiły mniej niż $5 \%$ populacji w wieku od 65- do 74 lat (8), nie został w Polsce nigdy spełniony.

\section{CEL}

Dla oceny trendu konieczne jest okresowe powtarzanie badań gerostomatologicznych. Celami podjętego przekrojowego polskiego badania regionalnego osób w wieku od 65 do 74 lat były ocena liczby zachowanych zębów, ciężkiej utraty zębów i bezzębia oraz ich porównanie w badaniach z ostatnich 30-lat. Dodatkowo wyniki tych obserwacji będą odniesione do aktualnych regionalnych danych europejskich, a także zostaną ustalone najważniejsze wskaźniki ryzyka zachowania i utraty zębów w ocenianej populacji.

\section{MATERIAŁ I METODY}

Badania dotyczyły 65-74 letnich mieszkańców dużego (Wrocław, 638 tys. mieszkańców) i małego miasta (Oława, 33 tys. mieszkańców) województwa dolnośląskiego. W celu wyboru grupy osób do badania epidemiologicznego w Ministerstwie Spraw Wewnętrznych i Administracji w Warszawie zastosowano metodę losowania dwuwarstwowego (pierwsza warstwa płeć, druga warstwa wiek). W jego wyniku wyłoniono grupę 1200 mieszkańców rejonu Wrocławia (dla Wrocławia i Oławy było to odpowiednio 800 oraz 400 osób) o symetrycznej strukturze wieku i płci. Liczebność jednostek w warstwie wieku była równa dla każdego roku życia, natomiast w warstwie płci odpowiadała proporcji ich liczebności dla obu miast w analizowanej grupie wiekowej. Do wszystkich wylosowanych osób wysłano następnie listownie zaproszenie do wzięcia udziału w bezpłatnym badaniu stanu zdrowia jamy ustnej. Osoby, dla których udało się ustalić prawidłowy numer, powiadomiono dodatkowo telefonicznie. W zaproszeniu zawarto informację o możliwości objęcia odpowiednim leczeniem stomatologicznym w ramach procedur refundowanych przez NFZ, jeśli stwierdzono by wskazania do takiego lecze- 
(including bacterial endocarditis in the past) and local contraindications (including acute odontogenic infection).

The research was conducted from June 25 to October 30, 2017. During this period, 387 people were examined (136 men and 149 women from Wrocław, as well as 50 men and 52 women from Olawa). The response rate for research was $32.25 \%$ (35.6\% for a large city and $25.5 \%$ for a small city).

Based on the interview conducted among patients who agreed to participate, the following information has been obtained: place of residence (Wrocław or Oława); age; gender; education (elementary, secondary, higher); general diseases: cardio-vascular diseases (conditions without incident, for instance coronary heart disease, cardiac arrhythmias or thrombotic diseases, and with a previous incident - myocardial infarction or stroke), hypertension, diabetes, osteoporosis - with the pharmacological treatment of the declared disease taken as the diagnostic criterion; the genetic predisposition to periodontitis in the medical history (the question whether family members like grandparents, parents or siblings lost their teeth because of the progressive mobility); smoking - according to the WHO (14) guidelines, the participants were qualified to the following groups: non-smokers (people who have never smoked or have smoked less than 100 cigarettes throughout their lives), ex-smokers (people who used to smoke regularly, but free of addiction at the time for a year at least), and current smokers (people who have smoked a minimum of 1 cigarette a day during the 6 months preceding the examination); income per capita in the household: the lowest (PLN 800 and below), the average (PLN 801-2500) and the highest (above PLN 2,500 ); oral health behaviors: average number of visits in the dental office during the previous 5 years (at least 2 visits per year were considered regular), frequency of brushing natural teeth or prostheses (brushing at least twice daily was considered regular) and daily additional cleaning of the interdental spaces with dental floss or a special brush (yes, no); forms of dental service: only in public facilities, only in private facilities or mixed way; the most common cause to seek dental treatment - the following options have been distinguished: oral cavity check-up, pain, aesthetic improvement, prosthetic treatment, gum bleeding or other reason; teeth loss reason: caries, periodontal disease and other causes (extraction of third molars was not taken into account).

The clinical examinations were conducted in LED lighting, with the use of a dental mirror and the $\mathrm{Hu}-$ Friedy periodontal probe PCP UNC 15.

The number of preserved natural teeth, excluding third molars, was recorded. Depending on the dentition status, the participants were categorized into the nia. Wszyscy trzej badający (specjaliści periodontolodzy) przeszli kalibrację w Zakładzie Periodontologii Uniwersytetu Medycznego we Wrocławiu przed rozpoczęciem badania.

Badania prowadzono $\mathrm{w}$ Zakładzie Periodontologii UM we Wrocławiu oraz w prywatnym specjalistycznym gabinecie dentystycznym w Oławie (Dentyści Olawa). Osoby zgłaszające się na badanie podpisywały oświadczenia zatwierdzone przez Komisję Bioetyczną przy UM we Wrocławiu (opinia nr KB-712/2017), wyrażając tym samym zgodę na uczestniczenie w badaniu i przetwarzanie uzyskanych danych. Kryteriami wykluczenia były przeciwwskazania ogólne (m.in. bakteryjne zapalenie wsierdzia w wywiadzie) i miejscowe (m.in. ostry stan zębopochodny) do badania stomatologicznego.

Badania prowadzono od 25 czerwca do 30 października 2017 roku. W tym okresie przebadano 387 osób (136 mężczyzn i 149 kobiet z Wrocławia oraz 50 mężczyzn i 52 kobiety z Oławy). Współczynnik zgłaszalności na badania wyniósł 32,25\% (35,6\% dla dużego miasta oraz $25,5 \%$ dla małego miasta).

Na podstawie wywiadu przeprowadzanego wśród pacjentów, którzy wyrazili chęć udziału w badaniach, uzyskiwano informacje odnośnie następujących zmiennych: miejsca zamieszkania (Wrocław lub Oława); wieku; płci; wykształcenia (podstawowe, średnie, wyższe); występowania chorób ogólnych: chorób sercowo-naczyniowych (uwzględniano stany bez incydentu np. choroba wieńcowa, zaburzenia rytmu serca lub choroby zakrzepowe i z przebytym incydentem - zawał mięśnia sercowego lub udar mózgu), nadciśnienia tętniczego, cukrzycy, osteoporozy - jako kryterium diagnostyczne przyjęto leczenie farmakologiczne deklarowanej choroby; genetycznego obciążenia zapaleniem przyzębia na podstawie informacji czy członkowie rodziny (dziadkowie, rodzice lub rodzeństwo) tracili zęby z powodu ich postępującej ruchomości; nikotynizmu - zgodnie z wytycznymi WHO (14) badanych kwalifikowano do następujących grup: osoby nigdy niepalące (osoby, które nigdy nie paliły tytoniu lub w ciągu całego swojego życia wypaliły poniżej 100 papierosów), byłych palaczy (osoby palące w przeszłości regularnie, ale od przynajmniej roku wolne od nałogu) oraz aktualnych palaczy (osoby wypalające minimum 1 papierosa dziennie w okresie 6 miesięcy poprzedzających badanie); dochodu na osobę w gospodarstwie domowym: najniższy $(800 \mathrm{zl}$ i poniżej), średni (801-2500zł) oraz najwyższy (powyżej $2500 \mathrm{zł}$ ); zachowań prozdrowotnych dotyczących jamy ustnej: średniej liczby wizyt $\mathrm{w}$ gabinecie dentystycznym w ciągu roku w ostatnich 5 latach (za regularne uznawano min.2 wizyty w roku), częstości szczotkowania zębów naturalnych lub protez (za regularne uznawano szczotkowanie przynajmniej 2 razy dziennie) oraz codziennego dodatkowego oczyszczania przestrzeni międzyzębowych nitką lub specjalną szczoteczką (tak, nie); formy finansowania leczenia stomatologicznego: korzystający z leczenia 
following groups: preservation of at least 21 teeth, severe tooth loss (preservation of 1 to 9 teeth) and edentulism. The presence of plaque on the vestibular and lingual surfaces of teeth was expressed by the modified PCR index according to O'Leary et al. (15). Correct toothbrushing corresponded to a value below $30 \%$ of PCR, values above $70 \%$ indicate to inefficient tooth brushing. To assess the effectiveness of interdental hygiene procedures the API index according to Lange et al. (16) was calculated. Proper interdental hygiene was evidenced by the API value below $25 \%$, values above $70 \%$ were interpreted as complete inability or lack of interdental space cleaning.

For all the groups in the descriptive statistics, mean values, median values, range (min-max), variances and standard deviations (SD) of the tested continuous parameters were calculated. Due to the lack of normal distribution of all variables, as verified by the Kolmogorov-Smirnov test with the Lilliefors correction, nonparametric tests were used. The verification of the hypothesis on equality of means in two groups was carried out with the Mann-Whitney test. The verification of the hypothesis about the equality of mean parameters in more than two groups was carried out with the Kruskal-Wallis rank sum test (homogeneity of variance was checked by the Levene test). For the parameters for which statistically significant differences were shown by the comparison of all 3 groups, multiple comparisons of mean ranks for all trials were carried out. For discrete parameters, the distribution frequency was analyzed by the $\chi^{2} \mathrm{df}$ test (sometimes V-square or $\chi^{2}$ with the Yates correction). Multifactor analysis was performed using logistic regression (estimation using the quasi-Newton method), calculating the adjusted odds ratio (OR) and $95 \%$ confidence interval for it $(95 \% \mathrm{CI})$.

For each test, $\mathrm{p} £ 0.05$ was considered statistically significant. The statistical analysis was carried out using Statistica 13.1, Excel 2016 software.

\section{RESULTS}

The average number of teeth preserved in the entire group was 13.07 (median 15, sum 5057). There were $14.2 \%$ of people with edentulism and with severe tooth loss $21.4 \%$. There were 5779 teeth missing in the entire study group, and only 1 person had the complete natural dentition. The main cause of tooth extraction was tooth decay (total $M_{\text {caries }} 4732$ ). There were definitely fewer extraction of teeth for periodontal reasons (total $\mathrm{M}_{\text {perio }}$ 1043). In Wrocław, there was a significantly higher mean number of teeth $(p=0.0005)$, more often there were functional teeth in the number above 20 teeth $(\mathrm{p}=$ 0.006), while in Oława, edentulism was more common $(p=0.013)$. Gender did not significantly affect any of the indicators of the number of teeth preserved. wyłącznie w ramach NFZ, wyłącznie opłacanego ze środków własnych bądź zarówno w ramach NFZ i prywatnie; najczęstszej przyczyny zgłaszania się do gabinetu stomatologicznego - wyróżniono następujące możliwości: badanie kontrolne stanu jamy ustnej, wystąpienie dolegliwości bólowych, poprawa estetyki uzębienia, leczenie protetyczne, krwawienie z dziąseł lub inna przyczyna; powodu utraty zębów: próchnica, choroby przyzębia oraz inna przyczyna. Nie uwzględniano przyczyny ekstrakcji trzecich zębów trzonowych.

Badania kliniczne prowadzono w oświetleniu lampy led, przy użyciu lusterka stomatologicznego oraz zgłębnika periodontologicznego $\mathrm{Hu}$ - Friedy PCPUNC 15.

$\mathrm{Na}$ podstawie klinicznego badania stomatologicznego rejestrowano liczbę zachowanych zębów naturalnych z wyłączeniem trzecich zębów trzonowych. W zależności od statusu zębowego kategoryzowano do następujących grup: zachowanie przynajmniej 21 zębów, ciężka utrata zębów (zachowanie od 1 do 9 zębów) oraz bezzębie. Występowanie płytki nazębnej na powierzchniach przedsionkowych i językowych zębów wyrażono poprzez zmodyfikowany wskaźnik PCR wg O'Leary i wsp. (15). Za wykładnik prawidłowego szczotkowania zębów przyjęto wartość tego wskaźnika poniżej 30\%, wartości powyżej $70 \%$ wskazywały na nieefektywne szczotkowanie zębów. Dla oceny skuteczności zabiegów higienicznych przeprowadzanych w przestrzeniach międzyzębowych obliczono wskaźnik API wg Lange i wsp. (16). O prawidłowej higienie $\mathrm{w}$ przestrzeniach międzyzębowych świadczyły wartość API poniżej 25\%, wartości powyżej $70 \%$ interpretowano jako całkowitą nieumiejętność lub brak oczyszczania przestrzeni międzyzębowych.

Dla wszystkich grup w statystykach opisowych zostały wyliczone wartości średnie, mediany, zakres (min-max), wariancje i odchylenia standardowe (SD) badanych parametrów ciągłych. W związku z brakiem normalności rozkładu wszystkich zmiennych, co zweryfikowano testem Kołmogorowa-Smirnowa z poprawką Lillieforsa, stosowano testy nieparametryczne. Weryfikację hipotezy o równości średnich w dwóch grupach przeprowadzono testem Manna-Whitneya, Weryfikację hipotezy o równości średnich parametrów w więcej niż dwóch grupach przeprowadzono testem sumy rang Kruskala-Wallisa (jednorodność wariancji sprawdzano testem Levene'a). Dla parametrów, dla których wykazano różnice istotnie statystyczne przy porównaniu wszystkich 3 grup przeprowadzono wielokrotne porównania średnich rang dla wszystkich prób. Dla parametrów dyskretnych rozkład częstości badano testem $\chi^{2} \mathrm{df}$ (niekiedy V-kwadrat lub $\chi^{2}$ z poprawką Yatesa). Analizę wieloczynnikową przeprowadzono wykorzystując regresję logistyczną (estymacja metodą quasi-Newtona), obliczając skorygowany iloraz szans (OR - odds ratio) i $95 \%$ przedział ufności dla niego $(95 \% \mathrm{CI}$ - confidence interval). 
Table I. Effect of analyzed variables on the presence of more than 20 natural teeth $(n=82)$ and on severe tooth loss (teeth number between 1 and 9) $(n=83)$

Tabela I. Wpływ analizowanych zmiennych na zachowanie liczby zębów powyżej 20 (n=82) oraz ciężką utratę zębów (liczba zębów od 1 do 9) $(\mathrm{n}=83)$

\begin{tabular}{|c|c|c|c|c|c|c|}
\hline \multirow{2}{*}{\begin{tabular}{l}
\multicolumn{1}{c}{ Variable } \\
$\begin{array}{l}\text { Place of } \\
\text { residence }\end{array}$
\end{tabular}} & \multicolumn{2}{|c|}{$\begin{array}{c}\mathrm{N} \text { of subjects with teeth }>\mathbf{2 0} \\
\text { Compared variables }\end{array}$} & \multirow{2}{*}{$\frac{\mathbf{p}}{0.006}$} & \multicolumn{2}{|c|}{$\begin{array}{c}\mathrm{N} \text { of subjects with severe tooth loss } \\
\text { Compared variables }\end{array}$} & \multirow{2}{*}{$\frac{\mathbf{p}}{0.25}$} \\
\hline & $\begin{array}{l}\text { Wrocław } \\
72(25.2 \%)\end{array}$ & $\begin{array}{c}\text { Oława } \\
10(9.8 \%)\end{array}$ & & $\begin{array}{c}\text { Wrocław } \\
57(22.1 \%)\end{array}$ & $\begin{array}{c}\text { Oława } \\
26(25.5 \%)\end{array}$ & \\
\hline Sex & $\begin{array}{l}\text { Females } \\
42(20.9 \%)\end{array}$ & $\begin{array}{c}\text { Males } \\
40(21.5 \%)\end{array}$ & 0.88 & $\begin{array}{l}\text { Females } \\
40(19.9 \%)\end{array}$ & $\begin{array}{c}\text { Males } \\
43(23.1 \%)\end{array}$ & 0.44 \\
\hline Education & $\begin{array}{c}\text { Basic } \\
10(11.8 \%)\end{array}$ & $\begin{array}{c}\text { High } \\
38(37.6 \%)\end{array}$ & 0.0001 & $\begin{array}{c}\text { Basic } \\
23(27.1 \%)\end{array}$ & $\begin{array}{l}\text { High } \\
13(12.9 \%)\end{array}$ & 0.018 \\
\hline Income & $\begin{array}{l}\text { Lower } \\
4(7 \%)\end{array}$ & $\begin{array}{c}\text { Higher } \\
25(24.8 \%)\end{array}$ & 0.0001 & $\begin{array}{c}\text { Lower } \\
15(26.3 \%)\end{array}$ & $\begin{array}{c}\text { Higher } \\
7(6.9 \%)\end{array}$ & 0.044 \\
\hline Smoking & $\begin{array}{c}\text { Never } \\
56(26.6 \%)\end{array}$ & $\begin{array}{c}\text { Current } \\
8(12.3 \%)\end{array}$ & 0.017 & $\begin{array}{c}\text { Never } \\
39(18.6 \%)\end{array}$ & $\begin{array}{c}\text { Current } \\
14(21.5 \%)\end{array}$ & 0.59 \\
\hline Diabetes & $\begin{array}{c}\text { Yes } \\
10(13.9 \%)\end{array}$ & $\begin{array}{c}\text { No } \\
72(22.8 \%)\end{array}$ & 0.093 & $\begin{array}{c}\text { Yes } \\
13(18.1 \%)\end{array}$ & $\begin{array}{c}\text { No } \\
70(22.2 \%)\end{array}$ & 0.44 \\
\hline $\begin{array}{l}\text { Cardio-vascular } \\
\text { disease }\end{array}$ & $\begin{array}{c}\text { Yes } \\
22(19.1 \%)\end{array}$ & $\begin{array}{c}\text { No } \\
60(22.1 \%)\end{array}$ & 0.52 & $\begin{array}{c}\text { Yes } \\
23(20 \%)\end{array}$ & $\begin{array}{l}\text { No } \\
60(22.1 \%)\end{array}$ & 0.65 \\
\hline $\begin{array}{l}\text { Cardiovascular } \\
\text { disease with } \\
\text { incidence }\end{array}$ & $\begin{array}{c}\text { Yes } \\
8(16.6 \%)\end{array}$ & $\begin{array}{c}\text { No } \\
74(21.8 \%)\end{array}$ & 0.41 & $\begin{array}{c}\text { Yes } \\
5(10.4 \%)\end{array}$ & $\begin{array}{c}\text { No } \\
78(23 \%)\end{array}$ & 0.072 \\
\hline Osteoporosis & $\begin{array}{c}\text { Yes } \\
13(30.2 \%)\end{array}$ & $\begin{array}{c}\text { No } \\
68(20.1 \%)\end{array}$ & 0.12 & $\begin{array}{c}\text { Yes } \\
9(20.9 \%)\end{array}$ & $\begin{array}{c}\text { No } \\
74(21.5 \%)\end{array}$ & 0.9 \\
\hline Hypertension & $\begin{array}{c}\text { Yes } \\
45(26 \%)\end{array}$ & $\begin{array}{c}\text { No } \\
37(17.3 \%)\end{array}$ & 0.037 & $\begin{array}{c}\text { Yes } \\
33(19.1 \%)\end{array}$ & $\begin{array}{c}\text { No } \\
50(23.4 \%)\end{array}$ & 0.3 \\
\hline Dental visits & $\begin{array}{l}\text { Regular } \\
37(28 \%)\end{array}$ & $\begin{array}{c}\text { Irregular } \\
45(17.6 \%)\end{array}$ & 0.018 & $\begin{array}{c}\text { Regular } \\
23(17.4 \%)\end{array}$ & $\begin{array}{c}\text { Irregular } \\
60(23.5 \%)\end{array}$ & 0.17 \\
\hline Toothbrushing & $\begin{array}{c}\text { Regular } \\
67(24.5 \%)\end{array}$ & $\begin{array}{c}\text { Irregular } \\
15(13.2 \%)\end{array}$ & 0.013 & $\begin{array}{c}\text { Regular } \\
53(19.4 \%)\end{array}$ & $\begin{array}{c}\text { Irregular } \\
30(26.3 \%)\end{array}$ & 0.13 \\
\hline $\begin{array}{l}\text { Interdental } \\
\text { hygiene }\end{array}$ & $\begin{array}{c}\text { Yes } \\
29(39.7 \%)\end{array}$ & $\begin{array}{c}\text { No } \\
53(16.8 \%)\end{array}$ & 0.0001 & $\begin{array}{c}\text { Yes } \\
4(5.5 \%)\end{array}$ & $\begin{array}{c}\text { No } \\
79(25.2 \%)\end{array}$ & 0.0004 \\
\hline Dental service & $\begin{array}{c}\text { Public } \\
11(8.3 \%)\end{array}$ & $\begin{array}{c}\text { Private } \\
55(40.4 \%)\end{array}$ & 0.0001 & $\begin{array}{c}\text { Public } \\
39(29.3 \%)\end{array}$ & $\begin{array}{c}\text { Private } \\
19(14 \%)\end{array}$ & 0.002 \\
\hline
\end{tabular}

Functional dentition was found in 82 , and severe tooth loss in 83 persons (Table 1). The number of teeth above 20 was statistically more frequent in people with higher education $(37.6 \%)$, with a highest income $(24.8 \%)$, and more often, in over $40 \%$, in persons paying in full for their dental treatment. In addition, functional dentition were significantly more frequently observed in non-smokers who were treated for hypertension, regularly seeking dental visits, regularly brushing teeth and regularly cleaning interdental spaces. In turn, severe loss of teeth significantly more often occurred in people with elementary education $(27.1 \%)$ and the lowest income (26.3\%) as well as in irregularly cleaning interdental spaces $(25.2 \%)$ and in less than $30 \%$ of subjets undergoing dental treatment from public funds.
Dla każdego testu $\mathrm{p} \leq 0.05$ uznawano za znaczące statystycznie. Analizę statystyczną przeprowadzono wykorzystując pakiet komputerowy Statistica 13.1, Excel 2016.

\section{WYNIKI}

Średnia liczba zachowanych zębów w całej grupie wynosiła 13,07 (mediana 15, suma 5 057). Osób bezzębnych było 55 (14,2\%), z ciężką utratą zębów $(21,4 \%$.) W całej grupie odnotowano brak 5779 zębów, a tylko 1 osoba zachowała kompletne uzębienie naturalne. Główną przyczyną ekstrakcji zębów była próchnica ( $U_{\text {caries }}$ suma 4 732). Ekstrakcje zębów z przyczyn periodontologicznych były zdecydowanie 
The highest number of preserved teeth (median 20) has been demonstrated in people with highest education and income and regularly cleaning interdental spaces (Table 2). In addition, the significant number of preserved teeth there was in persons paying in full for their dental treatment (median 19), regularly seeking dental visit (median 18), in people who have never been smokers (median 16.5) with the correct daily brushing teeth routine (median 16). rzadsze ( $U_{\text {perio }}$ suma 1043$)$. U mieszkańców Wrocławia występowała istotnie wyższa średnia liczba zębów $(p=0,0005)$, częściej występowało uzębienie funkcjonalne powyżej 20 zębów ( $p=0,006$ ), natomiast u mieszkańców Oławy częściej występowało bezzębie $(\mathrm{p}=0,013)$. Płeć nie wpływała znamiennie na żaden z wykładników liczby zachowanych zębów.

Table II. The influence of analysed variables on number of teeth

Tabela II. Wpływ analizowanych zmiennych na liczbę zębów

\begin{tabular}{|c|c|c|c|}
\hline \multicolumn{2}{|c|}{ Variable } & \multirow{2}{*}{$\begin{array}{c}\begin{array}{c}\text { Mean } \pm S D ; \text { Median } \\
\text { (minimum - maximum) }\end{array} \\
13.96 \pm 8.2 ; 15(0-28)\end{array}$} & $\mathrm{p}$ \\
\hline \multirow[t]{2}{*}{ Place of residence } & Wrocław & & \multirow[t]{2}{*}{0.0005} \\
\hline & Oława & $10.55 \pm 8.2 ; 11(0-26)$ & \\
\hline \multirow[t]{2}{*}{ Sex } & Females & $12.72 \pm 8.5 ; 14(0-28)$ & \multirow[t]{2}{*}{0.39} \\
\hline & Males & $13.44 \pm 8.1 ; 15(0-27$ & \\
\hline \multirow[t]{3}{*}{ Education } & Elementary (1) & $9.71 \pm 8.1 ; 9(0-25)$ & \multirow{3}{*}{$\begin{array}{l}0.0001 \\
\text { Difference between } 1 \text { st and others } \\
\mathrm{p}<0.0001\end{array}$} \\
\hline & Medium & $12.31 \pm 8.2 ; 13(0-28)$ & \\
\hline & Higher & $17.39 \pm 6.9 ; 20(0-27)$ & \\
\hline \multirow[t]{3}{*}{ Income } & Lowest & $7.82 \pm 7.6 ; 6(0-24)$ & \multirow{3}{*}{$\begin{array}{l}0,0001 \\
\text { Difference between all } \mathrm{p}<0.0001\end{array}$} \\
\hline & Average & $13.09 \pm 7.9 ; 13(0-28)$ & \\
\hline & Highest & $17.92 \pm 6.8 ; 20(0-27)$ & \\
\hline \multirow[t]{3}{*}{ Smoking } & Current & $11.51 \pm 8.2 ; 14(0-27)$ & \multirow{3}{*}{$\begin{array}{l}0.003 \\
\text { Difference between } 1 \text { st and others } \\
p=0.01\end{array}$} \\
\hline & Former & $11.7 \pm 7.9 ; 12(0-27)$ & \\
\hline & Never (1) & $14.3 \pm 8.4 ; 16.5(0-28)$ & \\
\hline \multirow[t]{2}{*}{ Diabetes mellitus } & Yes & $11.75 \pm 7.8 ; 13(0-27)$ & \multirow[t]{2}{*}{0.084} \\
\hline & No & $13.37 \pm 8.4 ; 15(0-28)$ & \\
\hline \multirow{3}{*}{$\begin{array}{l}\text { Cardio-vascular } \\
\text { diseases }\end{array}$} & No & $13.46 \pm 8.2 ; 15(0-27)$ & \multirow[t]{3}{*}{0.29} \\
\hline & Yes without incidence & $12.53 \pm 8.2 ; 13(0-27)$ & \\
\hline & Yes with incidence & $11.6 \pm 8.9 ; 14(0-28)$ & \\
\hline \multirow[t]{2}{*}{ Osteoporosis } & Yes & $14.02 \pm 8.8 ; 15(0-28)$ & \multirow[t]{2}{*}{0.38} \\
\hline & No & $12.95 \pm 8.3 ; 15(0-27)$ & \\
\hline \multirow[t]{2}{*}{ Dental visits } & Regularly & $16.25 \pm 6.4 ; 18(1-26)$ & \multirow[t]{2}{*}{0.0001} \\
\hline & Irregularly & $11.38 \pm 8.7 ; 11(0-28)$ & \\
\hline \multirow[t]{2}{*}{ Toothbrushing } & Regularly & $14.32 \pm 7.9 ; 16(0-28)$ & \multirow[t]{2}{*}{0.0001} \\
\hline & Irregularly & $9.8 \pm 8.4 ; 9(0-27)$ & \\
\hline \multirow[t]{2}{*}{ Interdental hygiene } & Yes & $19.12 \pm 5.0 ; 20(4-27)$ & \multirow[t]{2}{*}{0.0001} \\
\hline & No & $11.66 \pm 8.3 ; 12(0-28)$ & \\
\hline \multirow[t]{3}{*}{ Dental service } & Public & $8.12 \pm 7.9 ; 6(0-28)$ & \multirow{3}{*}{$\begin{array}{l}0.0001 \\
\text { Difference between all } \mathrm{p}<0.0001\end{array}$} \\
\hline & Mixed & $13.69 \pm 6.9 ; 15(0-27)$ & \\
\hline & Private & $17.37 \pm 7.3 ; 19(0-27)$ & \\
\hline
\end{tabular}

The data on the prevalence of edentulism is presented in Table 3. Most often, this condition has been observed in subjects treated only in public facilities $-30.8 \%$, in persons with previous cardio-vascular
Uzębienie funkcjonalne stwierdzono u 82, a ciężką utratę zębów u 83 osób (Tab. I). Liczba zębów powyżej 20 występowała statystycznie częściej u osób z wykształceniem wyższym $(37,6 \%)$, z miesięcznym docho- 
incidence $(27.1 \%)$, irregularly brushing teeth in the past $(25.4 \%)$, with elementary education $(23.5 \%)$, in people irregularly seeking dental visits $(21.6 \%)$ and never cleansing interdental spaces in the past (17.5\%).

Table 4 contains data on the results of logistic regression for effect independent variables on two extreme situations concerning the number of teethfunctional dentition and edentulism. The most clear $(p \leq 0.001)$ was the effect of the highest and lowest personal income and type of dental service- private or public on these diagnoses. In addition the probability of keeping more than 20 teeth depended on living in a large town, no smoking status and lack in medical history of genetic predisposition to periodontitis in combination with treated diabetes. The probability of edentulism is increased by the history of a cardiovascular incidence, whereas regular tooth brushing in past reduced this likelihood. dem osobniczym powyżej 2500 zł $(24,8 \%)$ oraz u ponad $40 \%$ osób samofinasujących leczenie stomatologiczne. Dodatkowo uzębienie funkcjonalne znamiennie częściej obserwowano u niepalących, leczonych z powodu nadciśnienia, regularnie odbywających wizyty stomatologiczne, regularnie szczotkujących zęby oraz oczyszczających dodatkowo przestrzenie międzyzębowe. $Z$ kolei ciężka utrata zębów istotnie częściej występowała u osób z wykształceniem podstawowym $(27,1 \%)$ i najniższym dochodem $(26,3 \%)$, a także u nieoczyszczających przestrzeni międzyzębowych $(25,2 \%)$ i u niespełna $30 \%$ leczących się stomatologiczne wyłącznie w ramach procedur NFZ.

Najwyższą liczbę zachowanych zębów (mediana 20) wykazano u osób z najwyższym wykształceniem i dochodem oraz u oczyszczających dodatkowo przestrzenie międzyzebowe (Tab II). Dodatkowo wykazano istotnie większą liczbę zachowanych zębów u osób samofinansujących leczenie stomatologiczne (mediana 19), regularnie kontrolujących stan uzębienia (mediana 18), niepalących nigdy tytoniu (mediana 16,5 ) i z prawidłowym dziennym wzorcem szczotkowania zębów (mediana 16).

Tabela III. Wpływ analizowanych zmiennych na występowanie bezzębia $(n=55)$

Table III. Effect of analyzed variables on the edentulism prevalence $(\mathrm{n}=55)$

\begin{tabular}{|c|c|c|c|}
\hline Variable & Number of & $\begin{array}{l}\text { ntulism (\%) } \\
\text { es }\end{array}$ & $\mathbf{p}$ \\
\hline Place of residence & $\begin{array}{l}\text { Wrocław } \\
33(11.6 \%)\end{array}$ & $\begin{array}{c}\text { Oława } \\
22(21.6 \%)\end{array}$ & 0.013 \\
\hline Sex & $\begin{array}{c}\text { Females } \\
32(15.9 \%)\end{array}$ & $\begin{array}{c}\text { Males } \\
23(12.4 \%)\end{array}$ & 0.25 \\
\hline Education & $\begin{array}{c}\text { Elementary } \\
20(23.5 \%)\end{array}$ & $\begin{array}{l}\text { Higher } \\
4(3.96 \%)\end{array}$ & 0.0002 \\
\hline Income & $\begin{array}{c}\text { Lowest } \\
19(33.3 \%)\end{array}$ & $\begin{array}{l}\text { Highest } \\
1(1.7 \%)\end{array}$ & 0.0001 \\
\hline Smoking & $\begin{array}{c}\text { Never } \\
26(12.4 \%)\end{array}$ & $\begin{array}{l}\text { Current } \\
13(20 \%)\end{array}$ & 0.12 \\
\hline Diabetes mellitus & $\begin{array}{c}\text { Yes } \\
11(15.4 \%)\end{array}$ & $\begin{array}{l}\text { No } \\
44(14 \%)\end{array}$ & 0.77 \\
\hline Cardio-vascular diseases & $\begin{array}{c}\text { Yes } \\
21(18.3 \%)\end{array}$ & $\begin{array}{c}\text { No } \\
34(12.5 \%)\end{array}$ & 0.14 \\
\hline Cardio-vascular diseases with incidence & $\begin{array}{c}\text { Yes } \\
13(27.1 \%)\end{array}$ & $\begin{array}{c}\text { No } \\
42(12.4 \%)\end{array}$ & 0.006 \\
\hline Osteoporosis & $\begin{array}{c}\text { Yes } \\
5(11.6 \%)\end{array}$ & $\begin{array}{l}\text { No } \\
50(14.5 \%)\end{array}$ & 0.77 \\
\hline Hypertension & $\begin{array}{c}\text { Yes } \\
23(13.3 \%)\end{array}$ & $\begin{array}{c}\text { No } \\
32(14.9 \%)\end{array}$ & 0.64 \\
\hline Dental visits & $\begin{array}{c}\text { Regularly } \\
0\end{array}$ & $\begin{array}{l}\text { Irregularly } \\
55(21.6 \%)\end{array}$ & 0.0001 \\
\hline Past toothbrushing & $\begin{array}{l}\text { Regularly } \\
26(9.5 \%)\end{array}$ & $\begin{array}{l}\text { Irregularly } \\
29(25.4 \%)\end{array}$ & 0.0001 \\
\hline Past interdental hygiene & $\begin{array}{c}\text { Yes } \\
0\end{array}$ & $\begin{array}{l}\text { No } \\
55(17.5 \%)\end{array}$ & 0.0002 \\
\hline Dental service & $\begin{array}{c}\text { Public } \\
41(30.8 \%)\end{array}$ & $\begin{array}{l}\text { Private } \\
6(4.4 \%)\end{array}$ & 0.0001 \\
\hline
\end{tabular}


Table IV. Adjusted odds ratio $(\mathrm{OR})^{*}$ and $95 \%$ confidence interval for prevalence of functional dentition and edentulism depending on the significant variables in logistic regression models

Tabela IV. Skorygowany* iloraz szans (OR) i 95\% przedział ufności $(95 \% \mathrm{Cl})$ dla występowania uzębienia funkcjonalnego oraz bezzębia w zależności od istotnych zmiennych w modelach regresji logistycznej

\begin{tabular}{|c|c|c|c|c|}
\hline \multirow{2}{*}{ Variables } & OR & Lower confidence interval & Upper confidence interval & $\mathbf{p}$ \\
\hline & \multicolumn{4}{|c|}{ Functional dentition } \\
\hline $\begin{array}{l}\text { Town } \\
\text { Wrocław } \\
\text { Oława }\end{array}$ & $\begin{array}{l}1 \text { (ref) } \\
0.118\end{array}$ & 0.033 & 0.422 & 0.001 \\
\hline $\begin{array}{l}\text { Income } \\
<2500 \mathrm{zł} \\
\geq 2500 \mathrm{zł}\end{array}$ & $\begin{array}{l}1 \text { (ref) } \\
9.375\end{array}$ & 3.084 & 28.496 & $<0.0001$ \\
\hline $\begin{array}{l}\text { Smoking } \\
\text { Current and former } \\
\text { Never }\end{array}$ & $\begin{array}{l}1 \text { (ref) } \\
0.402\end{array}$ & 0.196 & 0.825 & 0.013 \\
\hline $\begin{array}{l}\text { Dental service } \\
\text { Public } \\
\text { Private }\end{array}$ & $\begin{array}{l}1 \text { (ref) } \\
4.781\end{array}$ & 2.273 & 10.058 & $<0.0001$ \\
\hline \multirow[t]{2}{*}{$\begin{array}{l}\text { Genetic predisposition to } \\
\text { periodontitis and diabetes } \\
\text { treatment } \\
\text { Yes } \\
\text { No } \\
\end{array}$} & $\begin{array}{l}1 \text { (ref) } \\
0.013\end{array}$ & 0.0007 & 0.236 & 0.003 \\
\hline & \multicolumn{4}{|c|}{ Edentulism } \\
\hline $\begin{array}{l}\text { Income } \\
<2500 \mathrm{zt} \\
\geq 2500 \mathrm{zt}\end{array}$ & $\begin{array}{l}1 \text { (ref) } \\
0.256\end{array}$ & 0.116 & 0.564 & 0.001 \\
\hline $\begin{array}{l}\text { Cardiovascular disease } \\
\text { with incidence } \\
\text { Yes } \\
\text { No cardiovascular dis. }\end{array}$ & $\begin{array}{l}2.295 \\
1 \text { (ref) }\end{array}$ & 1.038 & 5.072 & 0.04 \\
\hline $\begin{array}{l}\text { Past toothbrushing } \\
\text { Irregular } \\
\text { Regular }\end{array}$ & $\begin{array}{l}1 \text { (ref) } \\
0.437\end{array}$ & 0.228 & 0.838 & 0.013 \\
\hline $\begin{array}{l}\text { Dental service } \\
\text { Public } \\
\text { Private }\end{array}$ & $\begin{array}{l}1 \text { (ref) } \\
0.464\end{array}$ & 0.296 & 0.726 & 0.001 \\
\hline
\end{tabular}

*ORs adjusted for age, sex, education

\section{DISCUSSION}

In the study population, from the potential number of all 10,836 teeth, 5,057 preserved teeth have been observed, meaning that most teeth $(53.33 \%)$ were removed. The presence of the functional dentition were demonstrated in $21.2 \%$ of participants (significantly more often in Wrocław $-25.2 \%$ vs. $9.8 \%$ in Oława), and severe tooth loss was observed in $21.4 \%$ of subjects. The mean number of preserved teeth in Wrocław seniors has significantly increased over the previous thirty years. In 1987, in the 60-80 age group, it was 9.86 (slightly higher in men -9.97 vs. 9.75 in women) (17). In 2013 (18) and currently in people aged 65-74, it oscillates around 14 teeth. The reduction
Dane dotyczące bezzębia przedstawiono w tabeli III. Występowało ono najczęściej u osób z najniższym dochodem (33,3\%). Wykazano istotnie częstsze jego występowanie u leczących się stomatologicznym wyłącznie w ramach procedur NFZ (30,8\%), u osób z przebytym incydentem sercowo-naczyniowym $(27,1 \%)$, nieregularnie szczotkującym w przeszłości zęby $(25,4 \%)$, z wykształceniem podstawowym $(23,5 \%)$, nieregularnie zgłaszającym się na kontrolne wizyty stomatologicznie $(21,6 \%)$ oraz nieoczyszczającym w przeszłości przestrzeni międzyzębowych $(17,5 \%)$.

W tabeli IV podano wyniki modeli regresji logistycznej dla wpływu niezależnych zmiennych na dwie skrajne sytuacje dotyczące liczby zębów: uzębienie funkcjonalne oraz bezzębie. Najbardziej jednoznaczny 
of the incidence of edentulism in the previous two decades is even more spectacular. In 1998 and 2002, the percentage of edentulous people aged 65-74 in the Lower Silesian Voivodship (monitoring studies also included residents of rural areas) was 44 and $60 \%$, respectively (12). Own observation indicated a more significant influence of place of residence than gender on the preservation of teeth by examined seniors. In Polish national studies $(12,19)$, the influence of gender on the number of teeth is noticeable - in 2002 the mean number of preserved teeth was more than 2 in men and the percentage of edentulism in women was higher by $7.6 \%$; in 2013 these differences were 1.6 and $3 \%$ respectively. Observations by foreign authors are controversial in this respect (20-22). This may indicate regional specifics in this respect, however, the effect of gender on tooth loss appears to be diminishing.

Even greater differences in the number of preserved teeth is revealed by a comparison of regional studies of European people at a similar age. Cross-sectional German study SHIP (Study of Health in Pomerania) was carried out in 2008-2012 among 554 participants aged 65-74, racially homogeneous, selected from inhabitants of towns and villages in the north-eastern region of this country (23). The main compared epidemiological results were similar to those in Wrocław - the mean number of teeth was 15.7 and the percentage of edentulism was $15.8 \%$. Cross-sectional Italian study was carried out in 2009-2010, concerning randomly selected 191 inhabitants of Turin, aged 60-75 (24). In this metropolitan center, these parameters were definitely better -20.6 teeth on average and only $3.5 \%$ of edentulism. These references show very different dental status among elderly inhabitants of urban region in Europe and this diversity is greater than in national studies.

In the studied population of Lower Silesian seniors, the direct medical reason of tooth loss was found for 5,775 of them: in $81,9 \%(4,732$ teeth in total and on average more than 12 teeth in an examined person) it was caries and in $18 \%(1,043)$ - it was periodontitis. Such dominance of caries as the main cause of tooth loss in the elderly is characteristic of poor developing countries, e.g. African ones (25). This structure shows that the generation born during World War II (today's 70 -year-olds) in Poland usually did not preserve its teeth due to cariological reasons. This regularity can be explained by the cohort effect of people born in the 1940s and exposed to decades of "extraction dentistry" associated with the focal infection theory prevailing in Eastern European countries and the perpetuation of abnormal medical and pro-health behavior of the population over the years. Extractions due to caries were in own examination strongly associated with such risk factors as socio-economic conditions- elementary wpływ na obie skrajne sytuacje miały najwyższy i najniższy dochód osobniczy oraz sposób finansowania leczenia stomatologicznego - prywatne i w ramach NFZ. Dodatkowo na zachowanie uzębienia funkcjonalnego wpływ miało zamieszkiwanie w dużym mieście, niepalenie tytoniu oraz brak w wywiadzie lekarskim obciążenia genetycznego zapaleniem przyzębia w połączeniu z leczeniem cukrzycy. Z kolei ze wzrostem prawdopodobieństwa występowania bezzębia istotnie związany był przebyty incydent sercowo-naczyniowy, natomiast ryzyko bezzębia istotnie zmniejszało regularne szczotkowanie zębów w przeszłości.

\section{DYSKUSJA}

W badanej populacji z potencjalnej liczby wszystkich 10836 zębów stwierdzono zachowanie 5057 zębów, czyli większość $(53,33 \%)$ została usunięta. Zachowanie uzębienia funkcjonalnego wykazano u 21,2\% osób (znamiennie częściej we Wrocławiu $-25,2 \%$ vs. 9,8\% w Olawie), a ciężką utratę zębów stwierdzono u $21,4 \%$ badanych. W ostatnich trzydziestu lat średnia liczba zachowanych zębów u seniorów wrocławskich znacząco się zwiększała. W 1987 roku w grupie wiekowej 60-80 lat wynosiła 9,86 (nieznacznie wyższa u mężczyzn 9,97 vs. 9,75 u kobiet) (17). W 2013 roku (18) i obecnie u osób w wieku 65-74 lat oscyluje wokół 14 zębów. W ostatnich dwóch dekadach jeszcze bardziej spektakularne jest zmniejszenie występowania bezzębia. W 1998 i 2002 roku odsetek osób bezzębnych w wieku 65-74 lata w województwie dolnośląskim (badania monitoringowe obejmowały także mieszkańców wsi) wynosił odpowiednio 44 i $60 \%$ (12). Obserwacja własna wskazała na bardziej znaczący wpływ miejsca zamieszkania niż płci na zachowanie zębów przez dolnośląskich seniorów. W polskich badaniach narodowych $(12,19)$ również zaciera się wpływ płci na liczbę zębów. W 2002 roku średnia liczba zachowanych zębów była o ponad 2 wyższa u mężczyzn, a odsetek bezzębia o 7,6\% u kobiet, w 2013 roku różnice te wynosiły odpowiednio 1,6 i 3\%. Obserwacje autorów zagranicznych są w tej kwestii kontrowersyjne (20-22). Wskazywać to może na regionalną specyfikę w tym zakresie, jednak wpływ płci na zachowanie zębów wydaje się zmniejszać.

Jeszcze większe różnice dotyczące liczby zachowanych zębów ujawnia porównanie regionalnych badań europejskich osób w zbliżonym wieku. W przekrojowym badaniu niemieckim SHIP (Study of Health in Pomerania) przeprowadzonym w latach 2008-2012 u wylosowanych 554 homogennych rasowo mieszkańców miast i wsi w północno-wschodnim rejonie tego kraju w wieku 65-74 lata uzyskano wyniki zbliżone do wrocławskich - średnia liczba zębów 15,7 a odsetek bezzębia $15,8 \%$ (23. W badaniu włoskim z lat 
education, lowest income, dental treatment only from public funds in the previous 13 years); abnormal oral behavior of subjects and living in a small town (data not shown).

In own study, the following factors were significantly associated with the average number of preserved teeth: individual income, education, type of dental treatment funding, behavioral factors-tooth brushing and flossing, frequency of dental visits; place of residence and smoking status. There was no statistically significant effect of gender and general disease (including diabetes). The highest income, self-financing of dental treatment, higher education, correct behavior regarding oral health, residing in Wrocław and never smoking were also the most important factors in preserving functional teeth. The factors significantly associated with severe tooth loss have been: lack of proper interdental hygiene, dental treatment exclusively in state-funded facilities in the previous 13 years, elementary education and the lowest income. These analyzes, therefore, indicate a very significant influence of the socioeconomic gradient on the number of preserved teeth. The impact of income (individual or family) seems the most documented. This is clearly confirmed by the meta-analysis of eight contemporary studies on the relationship between the lowest income range and tooth loss showing the overall odds ratio of 1.66 (confidence interval 1.48-1.86) calculated after adjusted confounding factors (26). The high income probably affects indirectly the better quality and choice of dental treatment strategies that preserve teeth, and it is usually associated with better education and more appropriate health-related oral behaviors and attaching importance to the aesthetics of the teeth. On the other hand, the lack of own financial resources for dental treatment limits the availability of treatment procedures (sometimes it limits them only to extractions performed in order to eliminate pain) and has an adverse psychological effect influencing the decision not to go to the dentist. Although own observations and other authors (20) confirm the dependence of dental status on education, noticeable sometimes in other studies (27) significant sensitivity of this factor to classical confounding variables may indicate that the effect of the educational gradient is not causative and only acts through other factors. In the multifactor analysis of the 5-year German SHIP cohort study, the prevalence of tooth loss was significantly and linked with the following in the given order: current smoking, education shorter than 10 years, the fourth highest BMI quantile and the lowest personal income (20). In the logistic regression model based on the Norwegian telephone survey of people aged 25 to 79 , it was shown that with preserving at least 20 teeth the factors statistically most closely related were:
2009-2010 dotyczącym wylosowanych trójwarstwowo 191 mieszkańców Turynu w wieku 60-75 lat wyniki te były zdecydowanie lepsze - 20,6 średnio zachowanych zębów i tylko 3,5\% odsetek bezzębia (24). Porównania te pokazują duże zróżnicowanie w liczbie zachowanych zębów przez osoby starsze pomiędzy regionami europejskimi, różnice te są większe niż w badaniach narodowych.

W badanej populacji dolnośląskich seniorów bezpośrednią przyczynę utraty zębów ustalono dla 5775 z nich i w 81,9\% (4 732 zęby i średnio ponad 12 zębów u badanego) była to próchnica, a tylko w 18\% (1043) zapalenia przyzębia. Taka dominacja próchnicy jako głównej przyczyny utraty zębów u osób starszych jest charakterystyczna dla biednych krajów rozwijających się np. afrykańskich (25). Struktura ta pokazuje, że pokolenie urodzone w czasie II wojny światowej w Polsce (dzisiejsi 70-latkowie) najczęściej nie zachowało swojego uzębienia z przyczyn kariologicznych. Prawidłowość tę może thumaczyć efekt kohorty, dotyczący osób urodzonych w latach 40. XX wieku i narażonych przez dekady na „stomatologię ekstrakcyjną" związaną z panującą w krajach Europy Wschodniej teorią odogniskową i utrwalanie przez lata nieprawidłowych decyzji lekarskich i zachowań prozdrowotnych populacji. Z ekstrakcjami z powodu próchnicy najsilniej związane były w badaniach własnych takie wskaźniki ryzyka jak uwarunkowania socjalno-ekonomiczne - wykształcenie podstawowe, najniższy dochód, leczenie stomatologiczne wyłącznie w ramach NFZ w ostatnich 13 latach; nieprawidłowe zachowania dotyczące zdrowia jamy ustnej oraz zamieszkanie w małym mieście (dane niepokazane).

W badaniu własnym ze średnią liczbą zachowanych zębów związane były istotnie następujące czynniki: dochód osobniczy, wykształcenie, rodzaj finansowania leczenia stomatologicznego, behawioralnedotyczące zachowań prozdrowotnych względem jamy ustnej, miejsce zamieszkania oraz status nikotynowy. Nie wykazano znamiennego statystycznie wpływu płci oraz chorób ogólnych (w tym cukrzycy). $\mathrm{Z}$ zachowaniem funkcjonalnego uzębienia najsilniej związane były również najwyższy dochód, samofinansowanie leczenia stomatologicznego, wykształcenie wyższe, prawidłowe zachowania dotyczące zdrowia jamy ustnej, mieszkanie we Wrocławiu oraz niepalenie nigdy tytoniu. Z ciężką utratą zębów znacząco związane były brak oczyszczania zębów w przestrzeniach międzyzębowych, leczenie stomatologiczne wyłącznie w ramach NFZ w ostatnich 13 latach, wykształcenie podstawowe i najniższy dochód. Analizy te wskazują zatem na bardzo znaczący wpływ gradientu socjalnoekonomicznego na liczbę zachowanych zębów. Najbardziej udokumentowane wydaje się oddziaływanie dochodu osobniczego lub rodzinnego. Potwierdza to 
the regularity of dental visits, the highest personal income, never smoking and living in the city (27). In a multifactor analysis referring to a cross-sectional Brazilian study, it was shown that severe loss of teeth was most closely related in a descending order to two lowest levels of education, visiting the dental office less than once every 2 years, the age over 80 and the third level of education (28). On the basis of the crosssectional Turkish study, a logistic regression model was also developed that indicated a significant effect on the loss of functional dentition in the order of impact of such variables as lack of any education, age from 70 to 74 and elementary and medium education (29). In Chilean multifactor analysis, adjusted for confounding factors, regarding the observation of people aged 65-74, no significant influence of personal income, family income, diabetes, depression and obesity on the loss of functional dentition was confirmed (although education was the closest to the level of significance: $\mathrm{p}=0.07)(30)$. The comparison of all these multifactor analyzes shows the variability of important factors affecting the number of teeth in individual countries. However, education is the most stable and important dependent variable.

The beneficial effect of a large agglomeration on the number of preserved teeth is probably due to the accumulation of other factors in Polish conditions, such as a higher percentage of richer and better educated people, easier access to dental treatment with preference towards saving teeth and greater pressure on the external appearance and related tooth aesthetics. In the future, we should expect a gradual decrease in the pressure of this condition on number of teeth.

Own observations and other authors $(20,27,31,32)$ consistently confirm the influence of the smoking on reducing the number of teeth. The evidence from cross-sectional and cohort studies indicates that the nature of this relationship is causal and independent of other factors. The strength of this relationship is moderate (higher in men), the effect is significantly higher in current smokers in relation to former ones and there is a dose-effect relationship. The model study for this subject, Potsdam study (31), shows that active male smokers over 60 face greater than doubled risk of losing their teeth by comparison to men who have never smoked, and after taking into account some confounding factors, an average number of teeth in a smoker is lower by $48 \%$. The biological basis of this relationship consists in the well-known destructive influence of smoking on tooth supporting tissues, impaired defense mechanisms, intensified carious processes as well as shifting the microbiological profile towards periopathogens. The risk of tooth loss due to smoking decreases gradually, reaching a level comparable with non-smokers only after 20 years (31). między innymi jednoznacznie metaanaliza Seeringa et al. ośmiu współczesnych badań związku pomiędzy najniższym przedziałem dochodowym a utratą zębów. pokazująca skumulowany iloraz szans o wartości 1,66 (przedział ufności 1,48-1,86) wyliczony po uwzględnieniu oddziaływania zmiennych zakłócających (26). Prawdopodobnie wysoki dochód w sposób pośredni wpływa na lepszą jakość i wybory strategii leczenia stomatologicznego zachowujących zęby, z reguły powiązany jest $\mathrm{z}$ lepszym wykształceniem i $\mathrm{z}$ właściwszymi zachowaniami prozdrowotnymi dotyczącymi jamy ustnej, a także z większym przywiązywaniem wagi do estetyki uzębienia. $Z$ drugiej strony brak własnych środków finansowych na leczenie stomatologiczne ogranicza dostępność procedur leczniczych (czasami ogranicza je tylko do ekstrakcji likwidujących ból) oraz wywiera niekorzystny efekt psychologiczny wpływający na decyzję o nieudaniu się do dentysty. Chociaż obserwacje własne i innych autorów (20) potwierdzają silną zależność statusu zębowego od wykształcenia, widoczna niekiedy w innych badaniach (27) znacząca czułość tego czynnika na klasyczne zmienne zakłócające może wskazywać, że efekt gradientu edukacyjnego nie jest przyczynowy i działa wyłącznie poprzez inne czynniki. W analizie wieloczynnikowej dotyczącej 5-letniego kohortowego badania niemieckiego SHIP nasilenie utraty zębów najsilniej związane było w kolejności z aktualnym nikotynizmem, edukacją krótszą niż 10 lat, czwartym najwyższym kwantylem BMI i najniższym progiem dochodu osobistego (20). W modelu regresji logistycznej powstałym na podstawie norweskiego badania telefonicznego osób w wieku od 25 do 79 lat wykazano, że z zachowaniem przynajmniej 20 zębów najsilniej związane były regularność wizyt $\mathrm{w}$ gabinecie stomatologicznym, najwyższy próg dochodu osobistego, niepalenie nigdy tytoniu i zamieszkiwanie w mieście (27). W analizie wieloczynnikowej odnoszącej się do przekrojowej badania brazylijskiego pokazano, że z ciężką utratą zębów najsilniej związane były w kolejności dwa najniższe poziomy edukacji, odwiedzanie gabinetu stomatologicznego rzadziej niż raz na 2 lata, wiek powyżej 80 lat oraz trzeci poziom edukacji (28). Na podstawie przekrojowego badania tureckiego także opracowano model regresji logistycznej wskazujący istotny wpływ na utratę funkcjonalności uzębienia w kolejności oddziaływania takich zmiennych jak brak jakiegokolwiek wykształcenia, wieku od 70 do 74 lat oraz wykształcenie podstawowe i średnie (29). W chilijskiej skorygowanej o zmienne zakłócające analizie wieloczynnikowej dotyczącej obserwacji osób w wieku od 65 do 74 lat nie potwierdzono istotnego wpływu na utratę funkcjonalności uzębienia wykształcenia, dochodu osobistego, dochodu rodzinnego, cukrzycy, depresji i otyłości (chociaż najbliżej poziomu istot- 
In the inhabitants of Wrocław and Oława there was no significant correlation between the number of teeth and selected general diseases (diabetes mellitus, cardio-vascular diseases without myocardial infarction or stroke incident, osteoporosis). The exception was the significantly higher number of teeth removed from periodontal indications in patients with a history of cardio-vascular events and a significantly higher incidence of functional dentition in people with hypertension treatment. This second dependence can be accidental, resulting from the accumulation of other variables in a group with hypertension. This correlation was not confirmed by Darnaud et al. (33)no significant association between systolic or diastolic hypertension and the number of teeth in people over 65; and more so by Peresa et al. (34)- significant association of systolic hypertension with tooth loss. The absence of significant influence of other analyzed in our study systemic diseases (in particular diabetes) on the number of preserved teeth was probably caused by the small sample size.

The prevalence of edentulism among young seniors in Wrockaw and the surrounding area was by more than half lower than that recorded in the last national study (19) for people of this age. Despite the significant decrease in the prevalence of edentulism examined seniors, it still remains one of the highest in Europe. The prevalence of edentulism among the examined seniors from the Lower Silesian Voivodship has been significantly related to the lowest income and education, living in a in small town, past cardiovascular incidence and determinants of bad oral health behaviors. Two-factor analyzes of other authors have also shown a significant relationship of edentulism with such socioeconomic factors as the lowest income $(21,28)$, lowest education $(21,29)$, the lowest quality of dental care or lack of it in connection with lack of health insurance $(28,29)$. The same as in own study factors associated with edentulism, confirmed in the observations of other authors, are the irregularity of visits to the dental office $(28,29)$ and the place of residence inside the country $(12,21,29)$. Similarly to our own study, other authors did not show a significant effect of gender $(21,29)$ and an active addiction to nicotine (28) upon edentulism. According to Liliestrand et al. (35), it appears that edentulism was significantly more common in people with coronary heart disease - HR 1.65 with a confidence interval (1.09-2.5), and the relationship with myocardial infarction was at the borderline significance level - HR 1.84 (0.99-3.42). Research by Górski et al. (36) showed significantly more frequent $(\mathrm{p}=0.04)$ prevalence of edentulism in patients with myocardial infarction with the reference to the control group of the same age without cardio-vascular disease. Edentulism is the end point of periodontitis ności było wykształcenie-p=0,07) (30). Porównanie tych wszystkich analiz wieloczynnikowych pokazuje zmienność istotnych czynników wpływających na liczbę zębów i rozpoznań, takich jak uzębienie funkcjonalne i ciężka utrata zębów w poszczególnych krajach. Jednak najbardziej stałą istotną zmienną zależną w tych analizach było wykształcenie.

Korzystny wpływ zamieszkiwania seniorów w dużej aglomeracji na liczbę zachowanych zębów wynika prawdopodobnie $\mathrm{w}$ warunkach polskich $\mathrm{z}$ kumulacji innych czynników np. wyższego odsetka osób bogatszych i lepiej wykształconych, większej dostępności do leczenia stomatologicznego preferującego utrzymanie zębów i większej presji na wygląd zewnętrzny i związaną z tym estetykę uzębienia. W przyszłości należy się spodziewać sukcesywnego zmniejszania się presji tego czynnika na liczbę zębów.

Zarówno obserwacje własne jak i innych autorów $(20,27,31,32)$ potwierdzają wpływ zespołu uzależnienia od tytoniu (ZUT) na istotne zmniejszenie liczby zębów. Dowody z badań przekrojowych i kohortowych wskazują, że natura tego związku jest przyczynowa i niezależna od innych czynników. Siła tego związku jest umiarkowana (większa u mężczyzn), efekt jest znacząco większy u aktualnych nikotynistów w odniesieniu do byłych oraz występuje zależność typu dawka-efekt. W modelowym dla tego zagadnienia badaniu Potsdam (31) pokazano, że aktywnie palący mężczyźni powyżej 60 roku życia mają ponad dwukrotnie większe ryzyko utraty zębów w odniesieniu do nigdy niepalących, a po uwzględnieniu zmiennych zakłócających nikotynista ma o 48\% niższą średnią liczbę zębów. Zależność ta wynika z dobrze znanego destrukcyjnego wpływu nikotynizmu na tkanki aparatu zawieszeniowego zębów, upośledzenia mechanizmów obronnych, nasilenia procesu próchnicowego, a także promowania profilu mikrobiologicznego w kierunku periopatogenów. Ryzyko utraty zębów związane z nikotynizmem zmniejsza się stopniowo, osiągając poziom porównywalny z osobami niepalącymi dopiero po 20 latach (31).

U mieszkańców Wrocławia i Oławy nie stwierdzono znaczącego związku liczby zachowanych zębów z wybranymi chorobami ogólnymi- cukrzycą, sercowo-naczyniowymi bez incydentu zawałowego lub udarowego, osteoporozą. Wyjątkiem była istotnie wyższa liczba zębów usuwanych ze wskazań periodontologicznych u osób $\mathrm{z}$ incydentem sercowo-naczyniowym $\mathrm{w}$ wywiadzie oraz znamiennie częstsze występowanie uzębienia funkcjonalnego u osób z leczonym nadciśnieniem. Ta druga zależność może mieć charakter przypadkowy, wynikająca z częstszego współwystępowania $\mathrm{w}$ grupie $\mathrm{z}$ nadciśnieniem innych zmiennych, powiązanych z zachowaniem zębów np. dochód. Zależności takiej nie potwierdziły bowiem 
and inflammatory complications associated with caries, and although with the removal of teeth systemic effects of inflammation cease to exist, the well-known earlier influence of oral inflammatory reactions on cardiovascular diseases and their complications was probably uninterrupted and long-term. In this way, we can explain own observations regarding the significantly more frequent occurrence of edentulism in patients with the history of a cardiovascular event. Liliestrand et al. (35) also showed a significant relationship between edentulism and diabetes - HR 1.56 (1.1-2.2), which was not confirmed in own observations and in studies of other authors (28).

Adjusted for age, sex and education logistic regression models were analysed of own material in terms of ranking the factors most strongly associated with differences in the number of teeth in two extreme situations, i.e. functional dentition and edentulism (Table 4). A very strong increase in the probability of functional dentition maintenance and a decrease in the likelihood of edentulism in people with the highest income and self-financing dental treatment were confirmed. Therefore, the economic gradient in the examined Lower Silesian population had a very significant impact on the maintenance of teeth in the seventh and eighth decade of life. An additional two factors significantly reducing the likelihood of keeping more than 20 natural teeth at this age are living in a small town and current or past smoking. A completely new factor indicated in the own model is a protective effect on maintaining the functional dentition identified in the medical history of the absence of familial predisposition to periodontitis in combination with the diabetes treatment. One of the suggested association of periodontitis and diabetes would be a common genetic factor conditioning the progressive nature of both diseases. Initially, a combination of polymorphisms IL-1A (-889) and IL-1B (+3953) was indicated, which would be responsible for the persistence of elevated levels of glycated hemoglobin and severe course of periodontitis (37). Subsequent studies, however, did not confirm this (38). Excessive DNA methylation of the CXCL12 promoter (constitutive chemokine) leading to increased glycosylation of hemoglobin and the incidence and severe course of periodontitis (39) is currently suggested. A systemic factor that more than doubled the risk of edentulism was a history of cardiovascular incidence. It is difficult to interpret unambiguously the direction of a significant relationship between edentulism and a cardiovascular incidence, on the basis of cross-sectional studies. Cohort observations (35) indicate that the impact of progressive tooth loss on cardiovascular diseases and their complication cannot be ruled out. badania Darnauda i wsp. (33) - brak znamiennego związku pomiędzy nadciśnieniem skurczowym lub rozkurczowym a liczbą zębów u osób powyżej 65 roku życia, a tym bardziej Peresa i wsp. (34) - istotny związek nadciśnienia skurczowego z utratą zębów. Brak wpływu innych analizowanych w naszym badaniu chorób systemowych (w szczególności cukrzycy) na liczbę zachowanych zębów mógł wynikać przypuszczalnie z małej liczebności grupy.

Występowanie bezzębia wśród seniorów Wrocławia i okolic było o ponad połowę niższe od wykazanego w ostatnim badaniu ogólnopolskim (19) osób w tym samym wieku. Z występowaniem bezzębia badanych seniorów z województwa dolnośląskiego znacząco związany był gradient wykształceniowo-ekonomiczny, mieszkanie w małym mieście, przebyty incydent sercowo-naczyniowy oraz uwarunkowania behawioralne dotyczące złych zachować prozdrowotnych względem jamy ustnej. W analizach dwuczynnikowych innych autorów również obserwowano istotny związek bezzębia z takimi czynnikami socjalnoekonomicznymi jak najniższy dochód $(21,28)$, najniższe wykształcenie $(21,29)$, najniższa jakość opieki stomatologicznej lub jej brak w powiązaniu $\mathrm{z}$ brakiem ubezpieczenia zdrowotnego $(28,29)$. Te same jak w badaniu własnym czynniki związane $\mathrm{z}$ bezzębiem potwierdzone $\mathrm{w}$ obserwacjach innych autorów to nieregularność wizyt $\mathrm{w}$ gabinecie stomatologicznym $(28,29)$ oraz miejsce zamieszkania wewnątrz kraju $(12,21,29)$. Podobnie jak w badaniu własnym inni autorzy nie wykazywali istotnego wpływu na bezzębie płci $(21,29)$ oraz czynnego i nałogowego nikotynizmu (28). Z badania Liliestranda i wsp. (35) wynika, że bezzębie występowało istotnie częściej u osób z chorobą wieńcową serca- HR 1,65 z przedziałem ufności (1,09-2,5), a związek z przebytym zawałem mięśnia sercowego był na granicy poziomu istotności- HR 1,84 $(0,99-3,42)$. Badania Górskiego i wsp. (36) wskazały na istotnie częstsze $(p=0,04)$ występowania bezzębia u pacjentów z pierwszym zawałem mięśnia sercowego w odniesieniu do grupy kontrolnej w tym samym wieku bez choroby sercowo-naczyniowej. Bezzębie to punkt końcowy zapaleń przyzębia oraz powikłań zapalnych związanych z próchnicą i chociaż wraz z usunięciem zębów ustaje systemowe oddziaływanie zapalenia, to dobrze znany wcześniejszy wpływ okołozębowych reakcji zapalnych na choroby sercowo-naczyniowe i ich powikłania był zapewne nieprzerwany i wieloletni. $\mathrm{W}$ ten sposób można tłumaczyć obserwacje własne dotyczące istotnie częstszego występowania bezzębia u pacjentów z incydentem sercowo-naczyniowym. Liliestrand i wsp. (35) wykazali ponadto istotny związek bezzębia z cukrzycą- HR 1,56 (1,1-2,2), czego nie potwierdzono $\mathrm{w}$ obserwacjach własnych oraz $\mathrm{w}$ badaniach innych autorów (28). 
The study has a some limitations that determine caution in formulating generalizations. First, it was a typical cross-sectional epidemiological study that measures exposure and health effects at the same time and therefore does not resolve the temporal relationship between two medical events. The second limitation is certainly the low response rate of elderly people for this study, which determines its low representativeness. It is not known if people reporting for a polish dental epidemiological study represent a better dental status and this is another check-up for them, or, which is less likely, they are people who have worse oral condition and are looking for help to improve it. It is also interesting to ask whether older people with edentulism who report for such an examination represent a true part of such a population. Another was limiting in own research only to the urban environment and omitting the rural one, which could also affect the assessed parameters of the condition of the oral cavity. Fourthly, many variables (especially concerning general health, e.g. former smoking) were determined anamnestic, which, especially for distant events, was associated with a high risk of error.

Based on the data analysed in the present study, it can be concluded that in the 30-year trend for Wrocław in people aged 65 to 74 years, the average number of teeth as well as the percentage of edentulism have improved, but they are still worse than the results of regional European studies. The main risk indicators of earlier loss of teeth by seniors in Lower Silesia are low income, past incorrect pro-health behaviours towards the oral cavity as well as current smoking and history of cardiovascular incidence.

\section{REFERENCES}

1. Jafarian M, Etebarian A. Reasons for extraction of permanent teeth in general dental practices in Tehran, Iran. Med Princ Pract. 2013; 22: 239-244.

2. Chrysanthakopoulos NA. Reasons for extraction of permanent teeth in Greece: a five-year followup study. Int Dent J. 2011; 61: 19-24.

3. Barbato PR, Peres KG. Contextual socioeconomic determinants of tooth loss in adults and elderly: a systematic review. Rev Braz Epidemiol. 2015;18: 357-371.

4. Fejerskov O, Escobar G, Jøssing M, Baelum V. A functional natural dentition for all and for life? The oral healthcare system needs revision. J Oral Rehabil. 2013; 40: 707-722.

5. Angelillo IF, Nobile CGA, Pavia M. Survey of reasons for extraction of permanent teeth in Italy. Community Dent Oral Epidemiol. 1996; 24: 336-340.

6. Faber M, Wiel AB, Exel E, Gussekloo J, Lagaay A, Dongen E, Knook DL, Geest S, Westendorp
W modelach regresji logistycznej dokonano skorygowanej o zmienne zakłócające analizy materiału własnego pod kątem uszeregowania czynników najsilniej związanych z różnicami w liczbie zębów w dwóch skrajnych sytuacjach, czyli w uzębieniu funkcjonalnym i bezzębiu (Tab. IV). Potwierdzono bardzo silny wzrost prawdopodobieństwa zachowania funkcjonalnego uzębienia oraz spadek prawdopodobieństwa występowania bezzębia u osób z najwyższym dochodem oraz samofinansujących leczenie stomatologiczne. Gradient ekonomiczny w badanej populacji dolnośląskiej miał zatem bardzo znaczący wpływ na zachowanie uzębienia w siódmej i ósmej dekadzie życia. Dodatkowe dwa czynniki znamiennie zmniejszające prawdopodobieństwo zachowania ponad 20 zębów naturalnych $\mathrm{w}$ tym wieku to zamieszkiwanie $\mathrm{w}$ małym mieście oraz aktualny lub przebyły zespół uzależnienia od tytoniu. Zupełnie nowym czynnikiem wskazanym w modelu własnym jest ochronne działanie na zachowanie funkcjonalności uzębienia stwierdzanych w wywiadzie medycznym braku występowania rodzinnego obciążenia zapaleniem przyzębia $\mathrm{w}$ połączeniu z leczoną cukrzycą. Jednym z sugerowanych związków zapalenia przyzębia prowadzącego do utraty funkcjonalności uzębienia i cukrzycy miałby być wspólny czynnik genetyczny warunkujący przewlekle postępujący charakter obu chorób. Początkowo wskazywano na kombinację polimorfizmów IL-1A (-889) i IL-1B (+3953), które odpowiadałyby za utrzymywanie się podwyższonego poziomu glikowanej hemoglobiny oraz ciężki przebieg periodontitis (37). Późniejsze badania jednak tego nie potwierdziły (38). Obecnie sugerowana jest nadmierna metylacja DNA promotora CXCL12 (chemokiny konstytutywnej) prowadząca do nasilenia glikozylacji hemoglobiny oraz do powstania i ciężkiego przebiegu zapalenia przyzębia (39). Czynnikiem ogólnym niezależnie zwiększającym ponad dwukrotnie ryzyko bezzębia był przebyty incydent sercowo-naczyniowy. Trudno na podstawie badań przekrojowych jednoznacznie interpretować kierunek tego związku. Obserwacje kohortowe (35) wskazują jednak, że nie można wykluczyć wpływu postępującej utraty zębów na choroby sercowo-naczyniowe i ich powikłania.

Przeprowadzone badania mają szereg ograniczeń, które determinują ostrożność w wyciąganiu uogólnień. Po pierwsze było to typowe przekrojowe badanie epidemiologiczne, które pomiary narażenia i skutku zdrowotnego dokonuje w tym samym czasie i w związku z tym nie rozstrzyga związku czasowego pomiędzy dwoma zdarzeniami medycznymi. Drugim ograniczeniem jest $\mathrm{z}$ pewnością niska zgłaszalność osób starszych na badanie, co decyduje o jego niskiej reprezentatywności. Nie wiadomo, czy osoby zgłaszające 
RG. Successful aging in the oldest old. Who can be characterized as successfully aged? Arch Intern Med. 2001; 161: 2694-2700.

7. WHO Expert Coomittee on Recent Advances in Oral Health. Recent advances in oral health: report of a WHO expert committee. W: WHO Technical Report Series. Geneva: World Health Organization; 1992: 1-38.

8. Hobdell M, Petersen PE, Clarkson J, Johnson N. Global goals for oral health 2020. Int Dent J. 2003; 53:285-288.

9. Nowjack-Raymer RE, Sheiham A. Numbers of natural teeth, diet, and nutritional status in US adults. J Dent Res. 2007; 86: 1171-1175.

10. Kassebaum NJ, Bernabe E, Dahiya M, Bhandari M, Murray CJL, Marcenes W. Global burden of severe tooth loss: a systemic review and metaanalysis. J Dent Res. 2014; 93: 20-28.

11. Lagerweij MD, van Loveren C. Declining caries trends: are we satisfied? Curr Oral Health Rep. 2015; 2:212-217.

12. Jodkowska E. The condition of dentition status of adult Polish citizens in years 1998-2009. Przegl Epidemiol, 2010; 64: 571-576 (in Polish).

13. Hugoson A, Koch G, Gothberg C, Helkimo AN, Lundin SA, NorderydO, Sjodin B, Sondell K. Oral health of individuals aged 3-80 years in Jonkoping, Sweden during 30 years (1973-2003) - II. Review of clinical and radiographic findings. Swed Dent J. 2005; 29: 139-155.

14. WHO: Guidelines for the conduct of tobacco smoking surveys for the general population. Geneva, 1983; 7-8.

15. O'Leary TJ, Drake RB, Naylor JE. The plaque control record. J. Periodontol. 1972; 43: 38.

16. Lange DE, Plagmann H-C, Eenboom A, Promesberger A. Klinische Bewertungsverfahren zur Objektivierung der Mundhygiene. Dtsch. Zahnärztl. Z. 1977; 32: 44-49 (in German).

17. Kaczmarek U, Potoczek S, Malepszy A, NowakMalinowska H, Semczuk-Mazurkiewicz D, Kuszej A, Kasiak M, Sozańska Z, Sender I, Radwan-Oczko $\mathrm{M}$. The state of dentition of men and women from Wrocław population. Wrocł Stomatol. 1987: 165171 (in Polish).

18. Konopka T, Zawada Ł, Kobierzycka A, Chrzęszczyk D. Periodontal condition in 35-44 and 65-74 year-old residents from lower Silesia region Dent. Med. Probl. 2015; 52: 447-454 (in Polish).

19. Konopka T, Dembowska E, Pietruska M, Dymalski P, Górska R. Periodontal status and selected parameters of oral condition of Poles aged from 65 to 74 years. Przegl Epidemiol. 2015; 69: 643 - 647 (in Polish). się w na polskie stomatologiczne badanie epidemiologiczne reprezentują lepszy status stomatologiczny $i$ jest to dla nich kolejne badanie kontrolne, czy, co mniej prawdopodobne, są to osoby reprezentujące gorszy stan jamy ustnej i szukają pomocy w jego poprawie. Ciekawe jest również pytanie, czy starsze osoby bezzębne zgłaszające się na takie badanie reprezentują prawdziwą część takiej populacji. Kolejne to ograniczenie się w badaniach własnych tylko do środowiska miejskiego i pominięcie wiejskiego, które mogło również wpływać na oceniane parametry stanu jamy ustnej. Po czwarte wiele zmiennych (szczególnie dotyczących ogólnego stanu zdrowia np. BMI) ustalano anamnestycznie, co szczególnie dla zdarzeń odległych obarczone było dużym ryzkiem błędu.

W podsumowaniu należy stwierdzić, że w 30-letnim trendzie dla Wrocławia u osób w wieku od 65 do 74 lat średnia liczba zachowanych zębów jak również odsetek bezzębia poprawiają się, lecz są jednak nadal gorsze od wyników regionalnych badań europejskich. Głównymi wskaźnikami ryzyka wcześniejszej utraty zębów przez seniorów dolnośląskich są niski dochód oraz nieprawidłowe wcześniejsze zachowania prozdrowotne względem jamy ustnej a także aktualny nikotynizm i przebyty incydent sercowo-naczyniowy.

20. Buchwald S, Kocher T, Biffar R, Harb A, Holtfreter B, Meisel P. Tooth loss and periodontitis by socioeconomic status and inflammation in a longitudinal population based study. J Clin Periodontol. 2013; 40: 203-211.

21. Slade GD, Akinkube AA, Sanders AE. Projections of U.S. edentulism prevalence following 5 decades of decline. J Dent Res. 2014; 93: 959-965.

22. Bernabe E, Sheiham A. Tooth loss in the United Kingdom- trend in social inequalities: an ageperiod-and-cohort analysis. Plos One, 2014; 9: 8, e104808.

23. Schützhold S, Kocher T, Biffar R, Hoffmann T, Schmidt CO, Micheelis W, Jordan R, Holtfreter B. Changes in prevalence of periodontitis in two German population-based studies. J Clin Periodontol 2015; 42: 121-130.

24. Aimetti M, Perotto S, Castiglione A, Mariani GM, Ferrarotti F, Romano F. Prevalence of periodontitis in an adult population from an urban area in North Italy: findings from a cross-sectional populationbased epidemiological survey. J Clin Periodontol 2015; 42: 622-631.

25. Kida IA, Åstrøm AN, Strand GV, Mosulu JR. Clinical and socio-behavioral correlates of tooth loss: a study of older adults in Tanzania. BMC Oral Health, 2006;6:5. 
26. Seering LM, Nascimento GC, Peres MA, Horta BL, Demarco FF. Tooth loss in adults and income: systemic review and meta-analysis. J Dent. 2015; 43: 1051-1059.

27. Haugejorden O, Klock KS, Åstrøm AN, Skaret E, Trovik TA. Socio-economic inequality in the selfreported number of natural teeth among Norwegian adults - an analytical study. Community Dent Oral Epidemiol 2008; 36: 269-278.

28. Ribeiro CG, Cascaes AM, Ribeiro Silva AE, Seerig LM. Et al. Edentulism, severe tooth loss and lack of functional dentition in elders: a study in Southern Brazil. Braz J Dent. 2016; 27: 345-342.

29. Doğan BG, Gökalp S. Tooth loss and edentulism in the Turkish elderly. Arch Gerontol Geriat. 2012; 54: e162-e166.

30. Urzua I, Mendoza C, Arteaga O, Rodriguez G, Cabello R, Faleiros S, Carvajal P, Munoz A, Espinoza I, Aranda W, Gamonal J. Dental caries prevalence and tooth loss in Chilean adult population: first national dental examination survey. Int J Dent. 2012, ID 810170.

31. Dietrich T, Walter C, Oluwagbemigun K, Bergmann M, Pischon T, Pischon N, Boeing H. Smoking, smoking cessation and risk of tooth loss: the EPICPotsdam study. J Dent Res. 2015; 94: 1369-1375.

32. Hugoson A, Rolandsson M. Periodontal disease in relation to smoking and the use of Swedish snus: epidemiological studies covering 20 years (19832003). J Clin Periodontol. 2011; 38: 809-816.

33. Darnaud C, Thomas F, Pannier B, Danchin N, Bouchard P. Oral health and blood pressure: the IPC cohort. Am J Hypertens. 2015; 28: 1257-1261.

34. Peres MA, Tsakos G, Barbeto PR, Silva DA, Peres $\mathrm{KG}$. Tooth loss is associated with increased blood pressure in adults- a multidisciplinary populationbased study. J Clin Periodontol. 2012; 39: 824-833.
35. Liljestrand JM, Havulinna AS, Paju S, Männistö S, Salomaa V, Pussinen PJ. Missing teeth predict incident cardiovascular events, diabetes and death. J Dent Res. 2015; 94: 1055-1062.

36. Górski B, Nargiełło E, Opolski G, Grabowska E, Górska R. Correlation between tooth loss and an increased risk of myocardial infarction in adult Polish population below 70 year of age- a casecontrol study. Nowa Stomatol. 2016; 21; 1: 30-39 (in Polish).

37. Struch F, Dau M, Schwahn C, Biffer R, Hocher $\mathrm{T}$, Meisel P. Interleukin-1 gene polymorphism, diabetes and periodontitis: result from the Study of Health in Pomerania- SHIP. J Periodontol. 2008, 79, 501-507.

38. Lopez NJ, Valenzuela CY, Jara L. Interleukin-1 gene cluster polymorphisms associated with periodontal disease in type 2 diabetes. J Periodontol. 2009; 80: 1590-1598.

39. Grdovic N, Rajic J, Petrovic SM, Dinic S, Uskovic A. Mihailovic M, Arambasic Jovanovic J, Tolic A, Pucar A, Milasin J, Vidakovic M. Association of CXCL12 gene promoter methylation with periodontitis in patients with diabetes mellitus type 2. Arch Oral Biol. 2016; 72: 124-133.

Received: 13.09.2019

Otrzymano: 13.09.2019 r.

Accepted for publication: 15.11.2019

Zaakceptowano do publikacji: 15.11.2019 r.

Address for correspondence: Adres do korespondencji:

Katedra i Zakład Periodontologii UM we Wrocławiu ul. Krakowska 26; 50-425 Wrocław tel. 717840381

e-mail: tomasz.konopka@umed.wroc.pl 